VI.

\title{
Contribution to the Biology of the Muttonfish, Zoarces anguillaris.
}

\author{
BY \\ Wilbert A. Clemens, Ph.D., \\ Assistant Professor in Biology, University of Toronto, \\ AND \\ Tucy Smith Clemens, Ph.D.
}

\section{INTRODUCTION.}

During the summer of 1918 at the St. Andrews Biological Station, St. Andrews, N.B., the writers commenced a study of the life-history of the muttonfish, or eelpout, (Zoarces anguillaris Peck). The primary object was to obtain some definite information in regard to the life-history and abundance of the fish relative to the possibility of placing it on the market and the results of that phase of the study have been published (Clemens, 1920).* There remain considerable scientific data which are presented here.

The writers are much indebted to Dr. A. G. Huntsman, Biologist to the Biological Board of Canada, for suggesting the study and for kind advice and assistance.

\section{HISTORICAI.}

Zoarces anguillaris was described by Peck (1804). Besides giving a detailed description, Peck states that the fish is taken on the haddock grounds, chiefly in the months of March and April, and that it feeds principally on echini and asteriæ. Since that time reports of capture have been numerous, but no study of the life history has hitherto been undertaken. Storer (1839) gives a list of stomach contents, and again (1867) describes the fish in detail with the addition of a good illustration. He also gives a further list of stomach contents and states that the fish is occasionally taken at all seasons of the jear but more frequently in the spring and summer. Goode (1884) states that it is frequently taken north of Cape Cod in winter with hook and line and that it spawns in July and August in the deep waters of Massachusetts bay. Nichols (1916) reports that it was taken throughout the year 1915 off New York and was especially abundant in June.

\section{DISTRIBUTION ALONG THE ATLAN'TIC COAST.}

The muttonfish occurs commonly along the Atlantic coast of Canada and northern United States, entering the bays and also the rivers for some distance. The extremes of its range reported at the present time are Bradore (?) Bay, Labrador, and Fort

* Issued in Bulletin No. IV in the Series "Histories of New Food Fishes. Biological Board of Canada, Ottawa, July, 1920. 
Macon, North Carolina. The following are the records of distribution as far as we have been able to ascertain. An asterisi is used to indicate those publications which have not been examined.

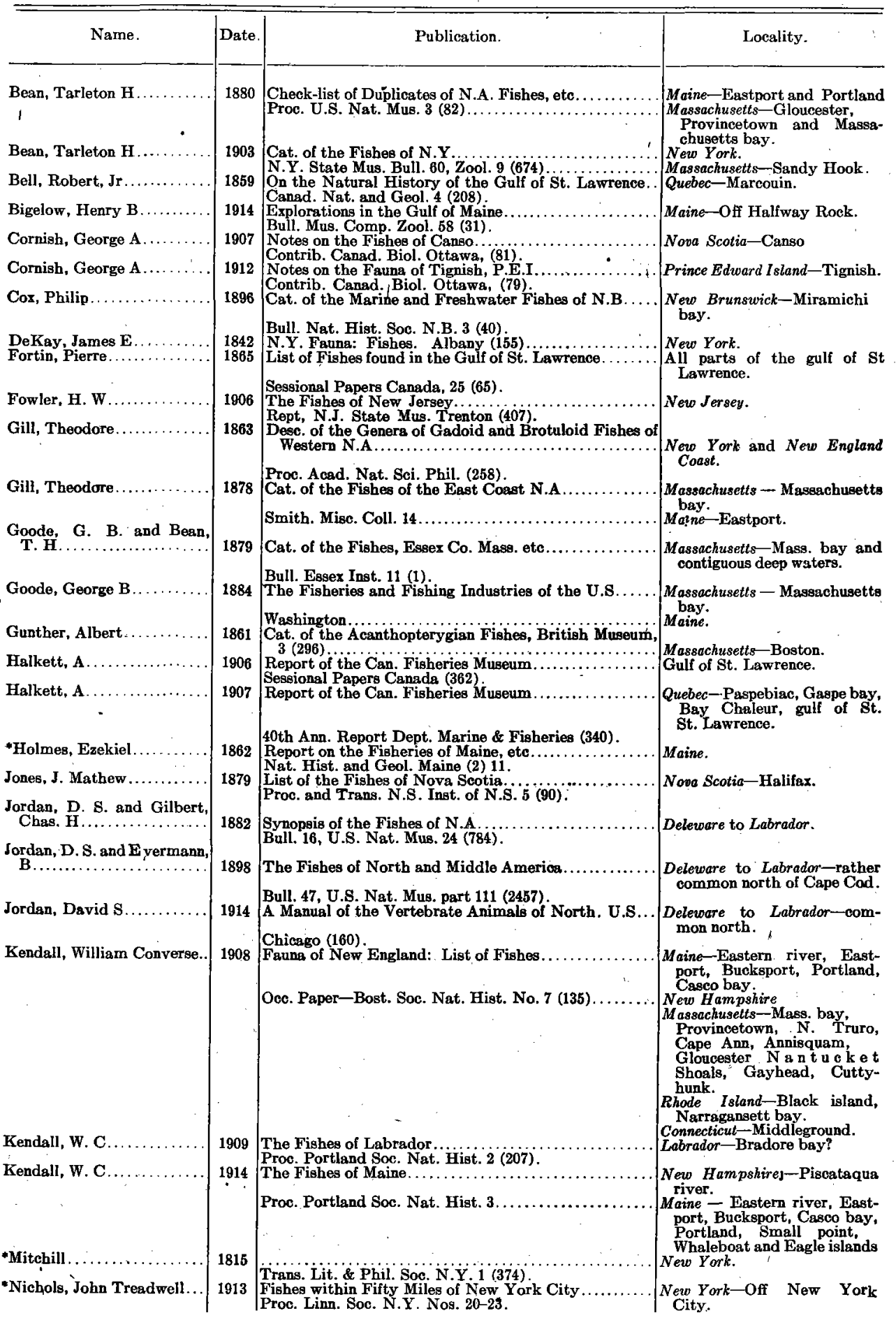




\begin{tabular}{|c|c|c|c|}
\hline Name. & Date. & - Publication. & Locality. \\
\hline Nichols, J. T............. & 1916 & $\begin{array}{l}\text { Seasonal Annotations on } 2 \text { Long Island Fishes......... } \\
\text { Copeia No. } 27(10) \text { : }\end{array}$ & $\begin{array}{l}\text { Newo York-Off New York } \\
\text { city. Cholera Bay. }\end{array}$ \\
\hline Peck, William D.. & $\begin{array}{l}1918 \\
1804\end{array}$ & $\begin{array}{l}\text { Fishes of the vicinity of New York City ........ } \\
\text { Handbook No. } 7 \text {, Am. Mus. Nat. Hist. ( }(\theta 1) . \\
\text { Description of Four Remarksble Fishes, etc ..... }\end{array}$ & $\begin{array}{l}\text { New York-Off New York. } \\
\text { New Hampshire-Near Piscata }\end{array}$ \\
\hline Schmitt, Joseph & 1904 & $\begin{array}{l}\text { Mem. Am. Aced. Ar ts and Sci. } 2 \text { (46). } \\
\text { Monographie de l'Ile d'Anticosti........ }\end{array}$ & $\begin{array}{l}\text { qua river. } \\
\text { Anticositisland-(Gulf of St. }\end{array}$ \\
\hline Smith, Hugh M & 1897 & $\begin{array}{l}\text { Paris (286). } \\
\text { Fishes found in the vicinity of Woods Hole. }\end{array}$ & $\begin{array}{l}\text { Lawrence). } \\
\text { Massachusetts- Gaybead, Cut- } \\
\text { tyhunk,. Vineyard sound, } \\
\text { Masaachusetts bay. }\end{array}$ \\
\hline Storer, David Humphreys. & 1839 & Bull. U.S. Fish Comm. (106). & Massachusetts. \\
\hline Storer, D. H. & 1846 & A Synopsis of the Fishes of. North America. . & $\begin{array}{l}\text { New Hampshire: Maine; Mass- } \\
\text { achusetts, New York. }\end{array}$ \\
\hline Storer, D. H. & 1867 & $\begin{array}{l}\text { Mem.Am. Acad. Arts and Soi. N. Ser. } 2 \text { (375). } \\
\text { A History of the Fishes of Mass. } \\
\text { Mem. Am. Acad. Arts and Sci. N. Ser. S (263). }\end{array}$ & Massachusetts. \\
\hline Storer, H. R.. & 1857 & 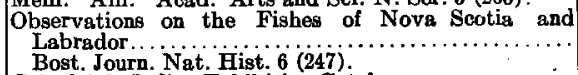 & Labrador-(Bradore?) \\
\hline Whiteaves, Joseph F. & 1886 & Colonial \& Indian Exhibition Catalogue $\ldots \ldots \ldots \ldots$ & $\begin{array}{l}\text { Atlantic Coast of Canada. } \\
\text { Gulf of St. Lawrence. }\end{array}$ \\
\hline Williamson, Wm. D. & 1832 & The History, of the State of Maine, $1(150) \ldots$. & $\begin{array}{l}\text { Maine-Eastern river and } \\
\text { other localities. }\end{array}$ \\
\hline Yarrow, H. C.. & 1877 & $\begin{array}{l}\text { Notes on the Natural History of Fort Macon, N.C. . } \\
\text { Proc. Acad. Nat. Sei. Phila. (206). }\end{array}$ & North Carolina-Fort Macon. \\
\hline
\end{tabular}

\section{LOCAL DISTRIBUTION AND MIGRATION.}

The map (fig. 2) below shows the distribution of the muttonfish in its northern range.

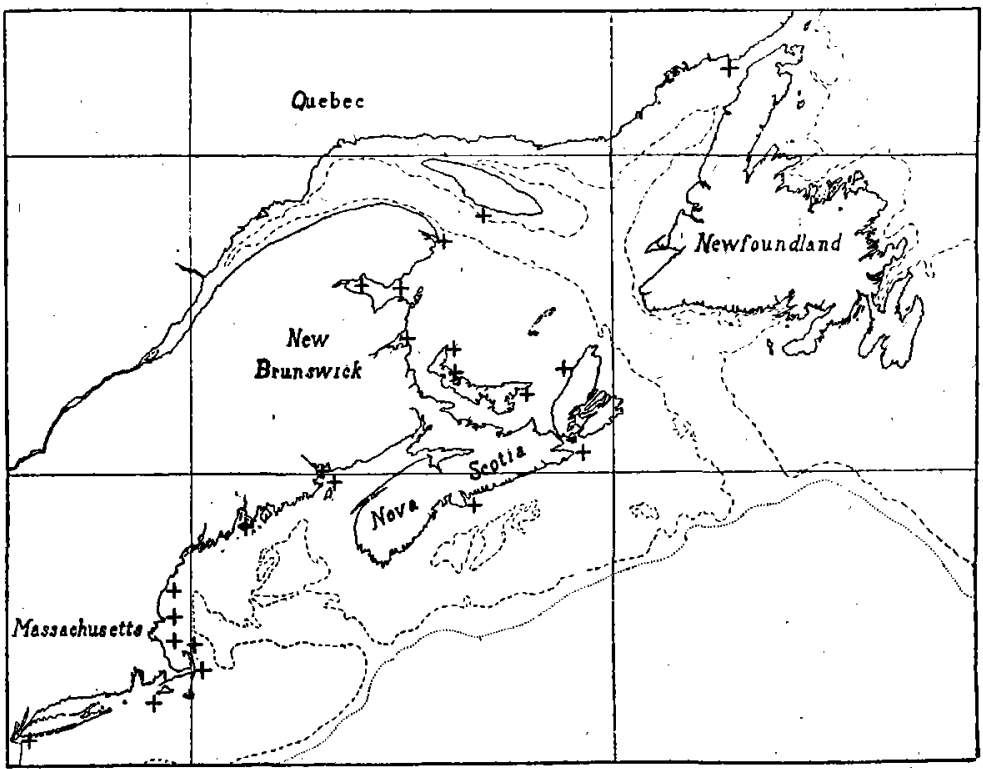

Fig. 2-Atlantic Coast with the localities from which the muttonfish has been reported shown by crosses.

Our knowledge of the habits, activities, migrations, breeding habits, etc., of the muttonfish is limited. Specimens kept in a large laboratory tank in 1918, remained 
coiled up in the darkest parts, but when disturbed swam swiftly and with power. The character of the food and the absence of swim' bladders indicate that they are bottom dwellers. During the summer months they are comparatively abundant in Passamaquoddy bay and in the lower portions of the St. Croix river. A few were taken in 1918 at a point about six miles up the St. Croix river and outward in the Bay of Fundy at the Wolves islands. In the course of the study specimens have been examined from the following localities: St. Croix river, Passamaquoddy bay, Bay of Fundy, including localities near the island of Grand Manan, Campobello island and the Wolves islands, St. Mary's bay, N.S., Miramichi bay (near Loggieville), Cheticamp (Cape Breton island) and gulf of St. Lawrence. They are most commonly taken by means of set likes but are also taken on hand lines, in herring traps, seines, lobster traps and various kinds of trawls. Young specimens are occasionally found around rocks and in seaweed along the shore during ebb tide. They occur on practically every variety of bottom in this region and at depths up to 55 metres. The following are the set line and shrimp trawl records for the Passamaquoddy bay region, with the addition of one record off Cape Breton island and another in Miramichi bay.

SET LINE RECORDS.

\begin{tabular}{|c|c|c|c|c|}
\hline Date. ." & Locality. & Sets. & Bait. & $\begin{array}{l}\text { No. Zogrces } \\
\text { per } 3,000 \\
\text { hooks. }\end{array}$ \\
\hline 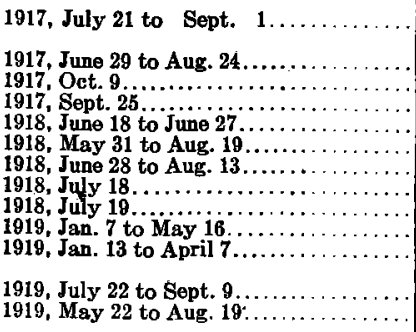 & 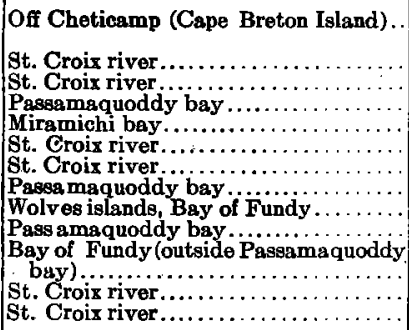 & $\begin{array}{r}3 \\
2 \\
1 \\
1 \\
5 \\
19 \\
10 \\
1 \\
1 \\
10 \\
4 \\
4 \\
4\end{array}$ & 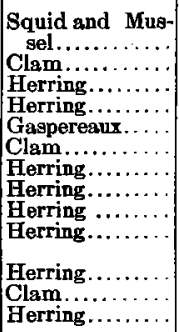 & $\begin{array}{r}6 \\
\mathbf{2 2} \\
14 \\
105 \\
9 \\
30 \\
12 \\
6 \\
1 \\
0 \\
0 \\
41 \\
6\end{array}$ \\
\hline
\end{tabular}

SHRIMP TRAWL RECORDS.

\begin{tabular}{|c|c|c|c|}
\hline Date. & Locality. & Depth in metres. & Number of Zoarces. \\
\hline 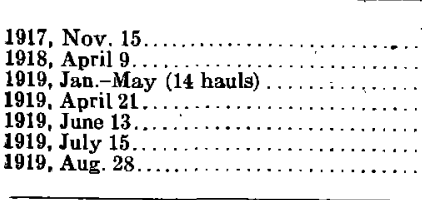 & $\begin{array}{l}\text { Passamaquoddy bay } \ldots \ldots \ldots \ldots \ldots \ldots \ldots \\
\text { Bay of Fundy } \ldots \ldots \ldots \ldots \ldots \ldots \ldots \\
\text { Passamaquoddy bay } \ldots \ldots \ldots \ldots \ldots \ldots \ldots \\
\text { Bay of Fundy } \ldots \ldots \ldots \ldots \ldots \ldots \ldots \\
\text { Passamaquoddy bay } \ldots \ldots \ldots \ldots \ldots \ldots\end{array}$ & $\begin{array}{c}\quad 25-30 \\
93 \\
\text { various depths } \\
? \\
30 \\
30 \\
25-30 \\
\end{array}$ & $\begin{array}{l}2 \\
1 \\
0 \\
1 \\
10 \\
8 \\
4\end{array}$ \\
\hline
\end{tabular}

The outstanding points in these records are:-

1. That the muttonfish is apparently absent from the St. Croix river and Passamaquoddy bay during at least four months of the year, from January to April.

2. The proportionately large capture in Passamaquoddy bay on September 25, 1917, may indicate a migration from the rivers into the bay prior to further migration into the Bay of Fundy.

3. The capture of a specimen on April 9, 1918, in the Bay of Fundy at a depth of 93 metres may be additional evidence of winter spent in the outer waters.

4. Where comparison is possible, clams (Mya arenaria) appear to be a better bait than herring (Clupea harengus). This agrees with the results of the food study, which shows that molluses form a very important part of the food, whereas fish are seldom eaten. 


\section{AGE ESTIMATION AND RATE OF GROW'TH.}

An estimation of the age and rate of growth of the muttonfish has been made from a study of the otoliths. The scales are very small and show no uniformity in annual growth areas. The vertebræ were found to be very unsatisfactory in the older fish because of the difficulty of distinguishing the rings toward the margins. However, in the younger specimens they were a valuable check on the otolith counts. The otoliths are comparatively small and regular in form and show clearly alternate light and dark areas. Final counts of the bands were made with the low power objective of the compound microscope upon ear-stones cleared and mounted in glycerine. No grinding down of the stones was necessary. In all, otoliths from ninety-one specimens have been examined. The method of computation has been somewhat the same as

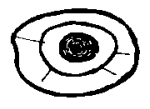

a

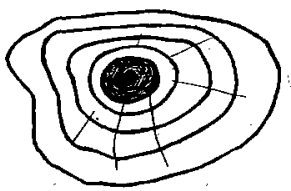

c

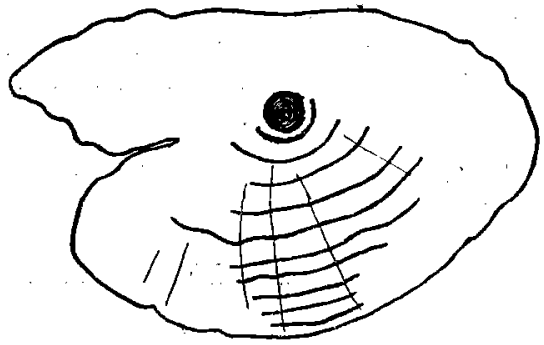

e

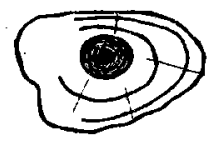

b
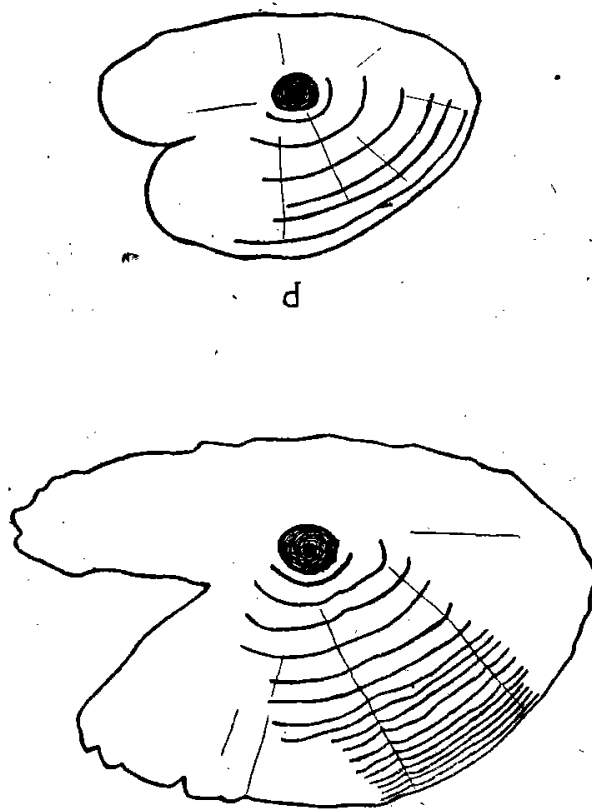

f

Fig. 3 Muttonfish otoliths drawn to the same scale.

(a) No. 119: $1.1 \mathrm{x} \cdot 7 \mathrm{~mm}$. Fish in flrst summer, $9.0 \mathrm{~cm}$. in length.

(b) No. $124: 1.5 \mathrm{x} .8 \mathrm{~mm}$. " "second summer, 12.6 cm. in length.

(c) No. $41: 2.2 \times 1.4 \mathrm{~mm}$. " " third summer, $21.0 \mathrm{~cm}$. in length.

(d) No. $98: 3.2 \times 2$ mm. " "sixth summer, $33.5 \mathrm{~cm}$. in length.

(e) No. $31: 4.2 \times 2.5 \mathrm{~mm}$. " " tenth summer, $51.5 \mathrm{~cm}$. in length.

(f) No. $33: 4.7 \times 3.0 \mathrm{~mm}$. “ " seventeenth summer, $61.5 \mathrm{~cm}$. in length.

that used by Fryd (1901) for Zoarces viviparus. He assumes that,during the winter a comparatively small amount of material is added to the otolith and this shows as a parrow opaque band or line. During the summer a comparatively large amount is added, which shows as a broad and much less opaque area. The dark centre 
or kernel is considered as the embroyonic beginning and the narrow light band immediately outside as representing the period in the body of the mother prior to birth, since the fish is ovoviviparous. The first dark band represents the remaining part of the winter period following birth, and the next broad light area, the first summer. From this on the' dark and light areas represent the succeeding winters and summers respectively. The otoliths of Zoarces anguillaris agree with the description given for those of Zoarces viviparus, but there is no evidence as yet to show that the muttonfish is ovoviviparous. Drawings have been made of six otoliths to illustrate the method of calculation and also to show the changes in shape of the otolith with increasing age (fig. 3). For example, the otolith of fig. $3(a)$ was taken on July 16, 1919, from a specimen $9 \mathrm{~cm}$. in length. It is exactly similar to others taken during the summer from specimens $7.5,8.0$ and $8.3 \mathrm{~cm}$. in length. It seems extremely probable that these muttonfish were in their first rear recause Zoarces viviparus grows much more rapidly than this, (Fryd 1oc. c.t.), and in Canadian waters, pollock, cod, haddock and hake attain considerably greater leng ${ }^{\text {ths }}$ in their first years. Moreover, specimens 2.5 and $3.7 \mathrm{~cm}$. have been taken in April and a growth of $1.5 \mathrm{~cm}$. per month during the months May; June and July would not be excessive. Unfortunately these small specimens were preserved in strong formalin and the otoliths disintegrated. The otoliths from the four larger specimn - show one winter ring. As will be shown later, the reproductive period undoubtedly occurs in the autumn, and therefore the first light area on the otolith probably represents a short period of very rapid growth in the autumn before the onset of winter conditions.

It should be stated here that in dealing with the otoliths many difficulties occurred. Bands are often indistinet; secondary lines tend to confuse the counts; the lines towards the margins become crowded together. It is a method of age estimation, not absolute determination. The difficulties are much the same as those met with in the scales of fish. Lea (1919) expresses the same opinion in his work with, the scales of herring (Clupea harengus). "That errors and uncertainty are unavoidable in investigations of this kind will be admitted by all who have had any experience of such work. The material may be handled with the highest possible degree of care and attention, so as to warrant the hope that a repetition of the determinations must give exactly the same results, yet on going through the whole once more, discrepancies will nevertheless be found. As a matter of fact, we are hardly justified in using the term "age-determination" when dealing with scales; "estimate" would be more correct, for there will always be found, whatever may be the material under consideration, a greater or less number of individuals whose scales must be classed as doubtful, and where the decision must be based more or less upon personal judgment."

\begin{tabular}{|c|c|c|c|c|c|c|}
\hline No. of Specimens.' & & Age. & Len & & $\begin{array}{l}\text { Estimated average } \\
\text { growth limits } \\
\text { in each year. }\end{array}$ & $\begin{array}{l}\text { Increase } \\
\text { in length per } \\
\text { year in } \mathrm{cm} .\end{array}$ \\
\hline 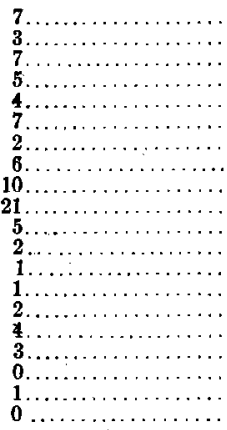 & 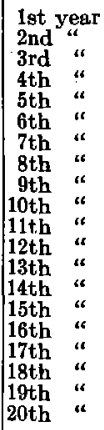 & 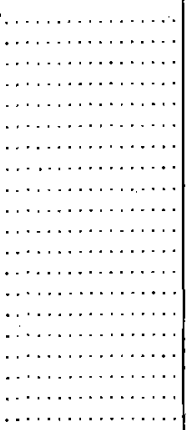 & 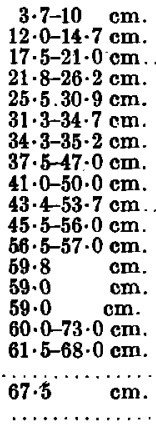 & 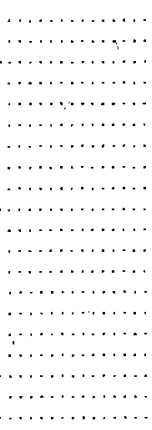 & $\begin{array}{r}1-10 \mathrm{~cm} . \\
10-16 \mathrm{~cm} . \\
16-21 \mathrm{~cm} . \\
21-26 \mathrm{~cm} . \\
26-31 \mathrm{~cm} . \\
31-35 \mathrm{~cm} . \\
35-39 \mathrm{~cm} . \\
39-43 \mathrm{~cm} . \\
43-46 \mathrm{~cm} . \\
46-49 \mathrm{~cm} . \\
49-52 \mathrm{~cm} . \\
52-55 \mathrm{~cm} . \\
55-58 \mathrm{~cm} . \\
58-60 \mathrm{~cm} . \\
60-62 \mathrm{~cm} . \\
62-64 \mathrm{~cm} . \\
64-66 \mathrm{~cm} . \\
66-68 \mathrm{~cm} . \\
68-69 \mathrm{~cm} . \\
66-70 \mathrm{~cm} .\end{array}$ & $\begin{array}{r}10 \\
6 \\
5 \\
5 \\
5 \\
4 \\
4 \\
4 \\
3 \\
3 \\
3 \\
3 \\
3 \\
3 \\
2 \\
2 \\
2 \\
2 \\
2 \\
1 \\
1 \\
1\end{array}$ \\
\hline
\end{tabular}


The first column shows the number of muttonfish of each age.

The second column gives the age as estimated by the otoliths.

- The third column shows the smallest and greatest lengths found for each age.

The fourth column gives the estimated average lengths for each year. . For example, it is estimated that on the average a muttonfish is $10 \mathrm{~cm}$. long at the end of the first year, $16 \mathrm{~cm}$. long at the end of the second year, $21 \mathrm{~cm}$. at the end of the third wear, etc.

The fifth column gives the probable average growth in $\mathrm{cm}$. for each year.-

The rate of growth is shown in fig. 4. The curve represents the estimated average lengths for each year. Since the majority of the young fish were taken in early summer, they would not have reached their growth limits for that year and therefore fall to the left of the curve.

\section{REPRODUGTION.}

It is impossible to distinguish the sexes externally except possibly in older specimens where the head of the male appears slightly larger and heavier than that of the female. Females in the environs of the St. Andrew's Biological Station from May 31 to October 15, 1918, contained eggs from less than $1 \mathrm{~mm}$. to $5 \mathrm{~mm}$. in diameter. A female $62 \mathrm{~cm}$. in length, weighing 3 pounds 12 ounces, and probably 17 years of age, contained $1,805 \mathrm{eggs} 5 \mathrm{~mm}$. in diameter. Seventy-nime specimens were opened, and the diameters of the eggs in the ovary and the lengths of the testes were measured. The results are given in the following two tables:-

EGGS IN OVARIES-DIAMETER.

\begin{tabular}{|c|c|c|c|c|c|}
\hline . & $0-1 \mathrm{~mm}$. & $1-2 \mathrm{~mm}$. & $2-3 \mathrm{~mm}$. & 3-4 mm. & 4-5 mm. \\
\hline May...... & $71 \mathrm{~cm}$. & & & & \\
\hline June $\ldots \ldots \ldots \ldots \ldots \ldots \ldots \ldots \ldots \ldots \ldots \ldots \ldots \ldots \ldots \ldots \ldots \ldots \ldots$ & & $\begin{array}{r}51 \mathrm{~cm} . \\
54.5 \mathrm{~cm} .\end{array}$ & $58 \cdot 5$ & & \\
\hline 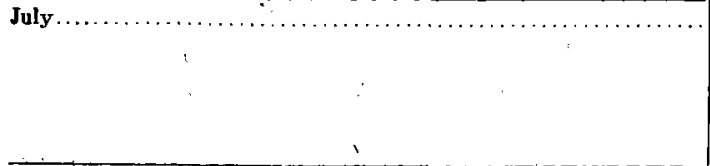 & $\begin{array}{l}21 \cdot 0 \\
26 \cdot 5 \\
27 \cdot 0 \\
40 \cdot 5 \\
41 \cdot 0 \\
54 \cdot 5 \\
61 \cdot 5\end{array}$ & $\begin{array}{l}33 \\
59\end{array}$ & $\begin{array}{l}57 \\
60 \cdot 5 \\
64 \cdot 8\end{array}$ & $\begin{array}{l}47 \\
48 \\
56\end{array}$ & $\begin{array}{l}49.5 \\
56.5 \\
57.0 \\
62.0\end{array}$ \\
\hline August $\ldots \ldots \ldots \ldots \ldots \ldots \ldots \ldots$ & $\begin{array}{l}37.5 \\
40 \cdot 5 \\
43 \\
45 \\
45 \\
45 \cdot 5 \\
50\end{array}$ & & . & 1 & \\
\hline September.... & $44 \cdot 0$ & & & & \\
\hline
\end{tabular}




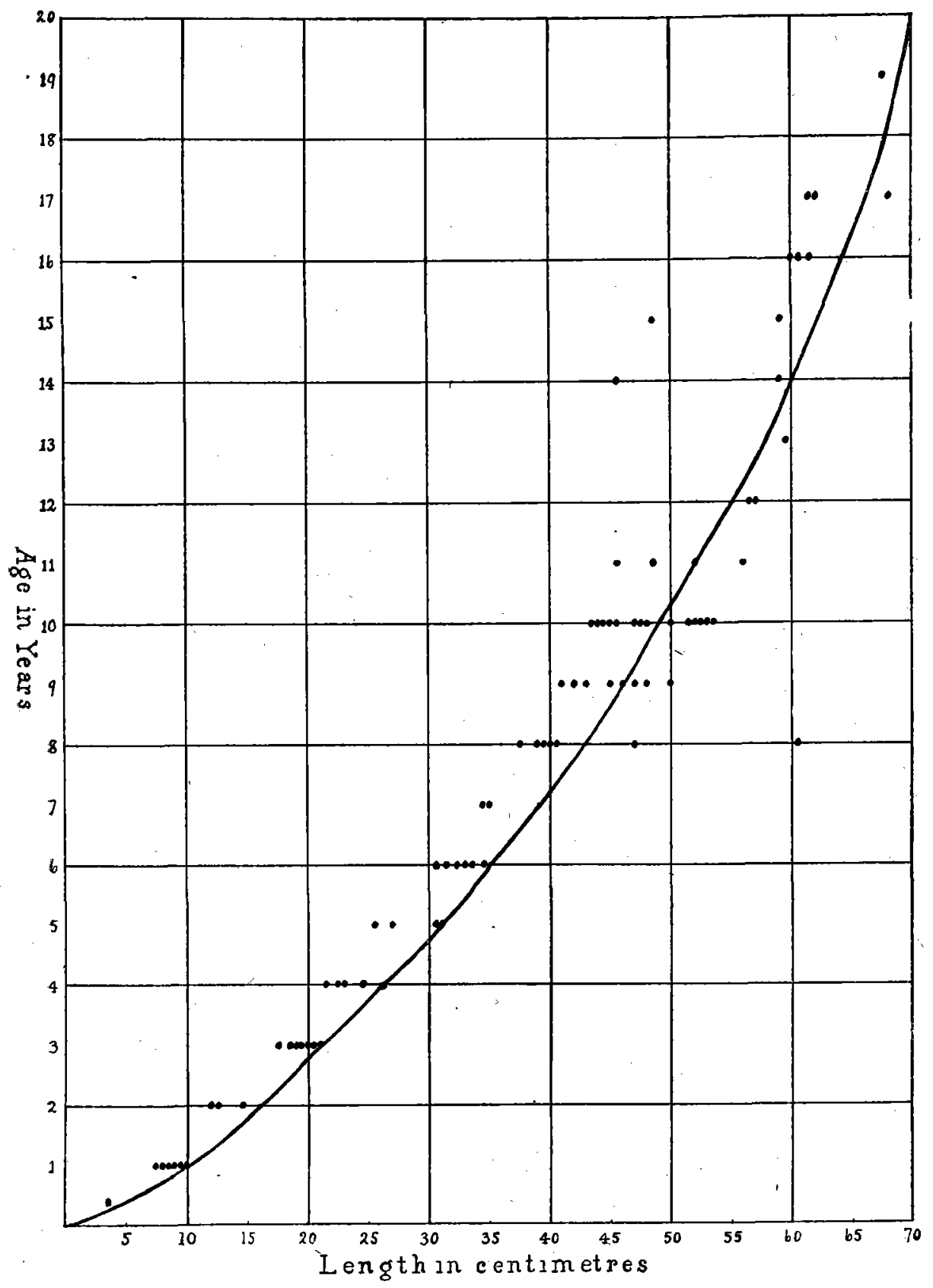

Fig. 4. Curve showing the rate of growth of the muttonfish. 
TESTES-LENGTH.

\begin{tabular}{|c|c|c|c|c|c|c|c|c|c|c|}
\hline & \multicolumn{2}{|c|}{ 1-2 cm. } & \multicolumn{2}{|c|}{ 2-3 em. } & \multicolumn{2}{|c|}{ 3-4 cm. } & \multicolumn{2}{|c|}{$4-5 \mathrm{~cm}$} & \multicolumn{2}{|c|}{ 5-6 om. } \\
\hline & Testes & Fish & Testes & Fish & Testes & Fish & Testes & Fish & Testes & Fish \\
\hline April $\ldots \ldots \ldots \ldots \ldots \ldots \ldots \ldots$ & & & $2 \cdot 3$ & $47 \cdot 0$. & $3 \cdot 5$ & $60 \cdot 0$ & & & & \\
\hline May $\ldots \ldots \ldots \ldots \ldots \ldots \ldots \ldots$ & & $:$ & $\begin{array}{l}2 \cdot 2 \\
2 \cdot 6 \\
\end{array}$ & $\begin{array}{l}43 \cdot 0 \\
54 \cdot 5\end{array}$ & & & ' & . & - & \\
\hline June $\ldots \ldots \ldots \ldots \ldots \ldots \ldots \ldots \ldots$ & $1.6 \mathrm{~cm}$ & $\stackrel{\mathrm{cm}}{34 \cdot \dot{0}}$ & $\begin{array}{l}2 \cdot 5 \\
2 \cdot 5 \\
2 \cdot 9 \\
\end{array}$ & $\begin{array}{l}49 \cdot 5 \\
50 \cdot 5 \\
66 \cdot 0\end{array}$ & $3 \cdot 2$ & $49 \cdot 5$ & $\therefore$ & & & \\
\hline 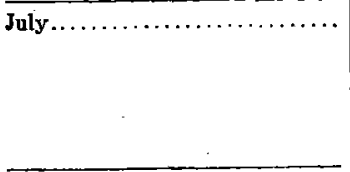 & $\begin{array}{l}6 \mathrm{~mm} \\
1.9 \mathrm{~cm}\end{array}$ & $\begin{array}{l}20 \cdot 5 \\
45 \cdot 5\end{array}$ & $\begin{array}{l}2 \cdot 4 \\
2 \cdot 8\end{array}$ & $\begin{array}{l}40 \cdot 0 \\
61 \cdot 5\end{array}$ & $\begin{array}{l}3 \cdot 0 \\
3 \cdot 2 \\
3 \cdot 2 \\
3 \cdot 4 \\
3 \cdot 4 \\
3 \cdot 5 \\
3 \cdot 5\end{array}$ & $\begin{array}{l}\mathbf{5 1} \cdot \mathbf{5} \\
\mathbf{5 4} \cdot 5 \\
60 \cdot 0 \\
\mathbf{4 5 \cdot 5} \\
\mathbf{5 1} \cdot \mathbf{5} \\
\mathbf{5 6} \cdot 0 \\
62 \cdot 0\end{array}$ & $\begin{array}{l}4 \cdot 0 \\
4 \cdot 0 \\
4 \cdot 0 \\
4 \cdot 0 \\
4 \cdot 1 \\
4 \cdot 5 \\
4 \cdot 6\end{array}$ & $\begin{array}{l}45 \cdot 0 \\
52 \cdot 0 \\
53 \cdot 0 \\
53 \cdot 0 \\
63 \cdot 5 \\
67 \cdot 5 \\
59 \cdot 0\end{array}$ & $\begin{array}{r}5 \cdot 0 \\
5 \cdot 8\end{array}$ & $\begin{array}{l}53 \cdot 5 \\
83 \cdot 0\end{array}$ \\
\hline Average for July ............ & & $33 \cdot 0$ & & $50 \cdot 5$ & & $54 \cdot 5$ & & $57 \cdot 0$ & & 68.0 \\
\hline 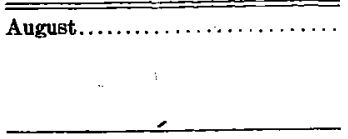 & $1 \cdot 6$ & $42 \cdot 0$ & $\begin{array}{l}2 \cdot 0 \\
2 \cdot 5 \\
2 \cdot 6 \\
2 \cdot 7 \\
2 \cdot 9\end{array}$ & $\begin{array}{l}43 \cdot 5 \\
44 \cdot 5 \\
43 \cdot 5 \\
39 \cdot 0 \\
47 \cdot 5\end{array}$ & $\begin{array}{l}3 \cdot 0 \\
3 \cdot 5 \\
3 \cdot 6 \\
3 \cdot 9\end{array}$ & $\begin{array}{l}4 \mathbf{6} \cdot 0 \\
48 \cdot 5 \\
44 \cdot 0 \\
52 \cdot 0\end{array}$ & $\begin{array}{l}4 \cdot 0 \\
4 \cdot 0 \\
4 \cdot 2 \\
4 \cdot 2\end{array}$ & $\begin{array}{l}48.0 \\
50.0 \\
47.0 \\
48.0\end{array}$ & & \\
\hline Average for August. ............. & & $42 \cdot 0$ & & $43 \cdot 0$ & & $47 \cdot 5$ & & $48 \cdot 0$ & . & \\
\hline September .................. & $1 \cdot 4$ & $36 \cdot 0$ & & & & & & & & \\
\hline$\overline{\text { October }} \ldots \ldots \ldots \ldots \ldots \ldots \ldots \ldots$, & $1 \cdot 4$ & $33 \cdot 5$ & $\begin{array}{l}2 \cdot 0 \\
2 \cdot 2\end{array}$ & $\begin{array}{l}43 \cdot 0 \\
47 \cdot 5\end{array}$ & $3 \cdot 0$ & $60 \cdot 5$ & & & , & \\
\hline
\end{tabular}

Examination of the tables shows-

(1) that as a rule the larger females contained the larger eggs and that no specimens with large eggs were taken later than July;

(2) similarly the larger males contained the larger testes and the larger males tended to disappear in August.

These results are then evidence-

(1) that a fall migration occurs and corroborates the set line and shrimp trawl records;

(2) that the reproductive period occurs in the fall of the year since the sexually mature fish disappear early in August and since no "spent" males or females were taken from May to October, 1918. Two captures tend to substantiate this. On April 15, 1919, a muttonfish $3.7 \mathrm{~cm}$. in length was found in the stomach of a sculpin (Myoxocephalus octodecimspinosus) taken in a seine in St. Andrew's bay. Also on April 21, 1919, an imperfect specimen $2.5 \mathrm{~cm}$. in length was taken in a shrimp trawl in the Bay of Fundy. As previously stated there is mo doubt but that these small specimens were produced during late fall or early winter. This would coincide with the period given for Zoarces viviparus (McIntosh, 1885, and Van Bambeke, 1888);

(3) that the fish do not become sexually mature until they have attained a length of about 40 to $45 \mathrm{~cm}$. According to the age estimations the fish would be about eight years of age;

(4) that reproduction may not occur every year in some, possibly in all individuals. In late July there were large females containing small eggs and large males with small testes. Also there were taken occasional large specimens later than July with small eggs and small testes. For example, a female $61.5 \mathrm{~cm}$. in length taken on July 10, 1918, had eggs only $1 \mathrm{~mm}$. in diameter; another $59 \mathrm{~cm}$, taken July 26, 1918, had eggs only $1.5 \mathrm{~mm}$. in diameter; and another $50 \mathrm{~cm}$., on August 21,1918 , had eggs $1 \mathrm{~mm}$. in diameter. It is doubtful if these eggs would have matured that season. 
Whether Zoarces anguillaris resembles Zoarces viviparus in being ovoviviparous has not been determined. Goode (loc. cit.) states that the fish spawns in July and August in the deep waters of Massachusetts bay; but gives no evidence in support of his statement.

McIntosh (loc. cit.) states that Zoarces viviparus in Scottish waters may liberate young up to the lengh of $4.5 \mathrm{~cm}$. Van Bambeke (loc. cit.) states that females of this species from 30-39 $\mathrm{cm}$. in length contain from 200-400 young. Fryd (loc. cit.) gives about 100 young for specimens $30 \mathrm{~cm}$. in length, and 205 for a specimen $37.7 \mathrm{~cm}$. in length. Bridges (1904) gives the number of young produced as $20-300$ or more according to the size of the female and adds that the eggs hatch in about 20 days, and the young are not born until about four months after fertilization when they are about $1 \frac{1}{2}$ inches long. It is apparent that a much smaller number of eggs mature in Zoarces viviparus than in Zoarces anguillaris. If the muttonfish is ovoviviparous it is not probable that it would retain 1,800 young until they attain a length of $4.5 \mathrm{~cm}$. They would probably only be about 1 or $1.5 \mathrm{~cm}$. in length when liberated since the young reach a length of only 2.5 to $3.7 \mathrm{~cm}$. by April. It is unlikely that this short period would have any relation to the first light area surrounding the "nucleus" of the otolith.

\section{RELATION OF TEMPERATURE TO THE PERIODS OF MIGRATION AND REPRODUCTION.}

The extremes of temperature for the bottom waters of the St. Croix river, Passamaquoddy bay and the Bay of Fundy in 1916 and 1917 are shown in the following table. The writers are indebted to Professor A. Vachon, Laval University, for these records.

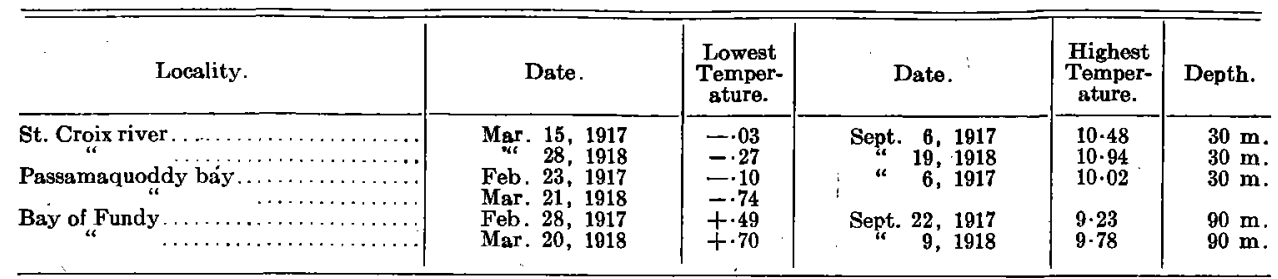

The sexually mature muttonfish leave the St. Croix river and Passamaquoddy bay about the end of July, and the remainder probably have left by the end of October. The height of the outward migration therefore occurs at the period of highest temperature. The inward migration probably begins early in April, which is the time when the temperature of the water in the St. Croix river and Passamaquoddy bay goes above $0^{\circ} \mathrm{C}$. Fertilization of the eggs probably occurs in September which is the period of highest bottom temperature. There is thus a coincidence between the temperature extremes and the migration periods, but whether or not there is a causal relation it is impossible to decide at the present time.

\section{RELATION OF WEIGHT TO AGE, LENGTH AND SEX.}

The following table shows the relation of the weight to the age and length and gives the probable average increase in weight for each year.

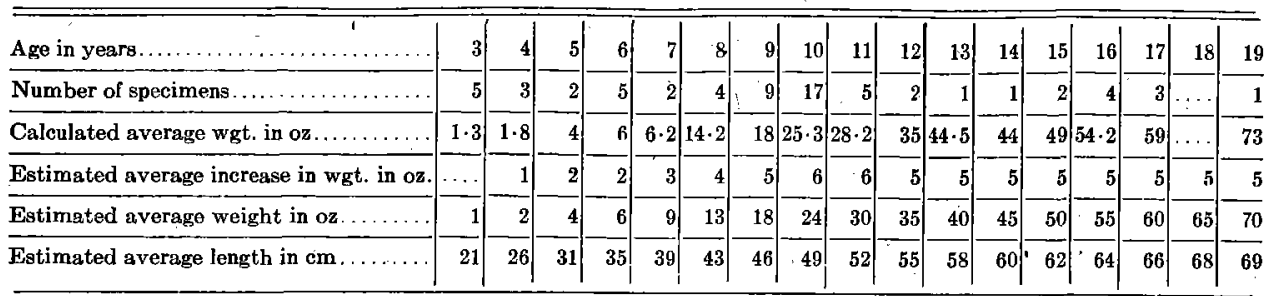


Figure 5 below is a graph showing more clearly the relation of weight to length.

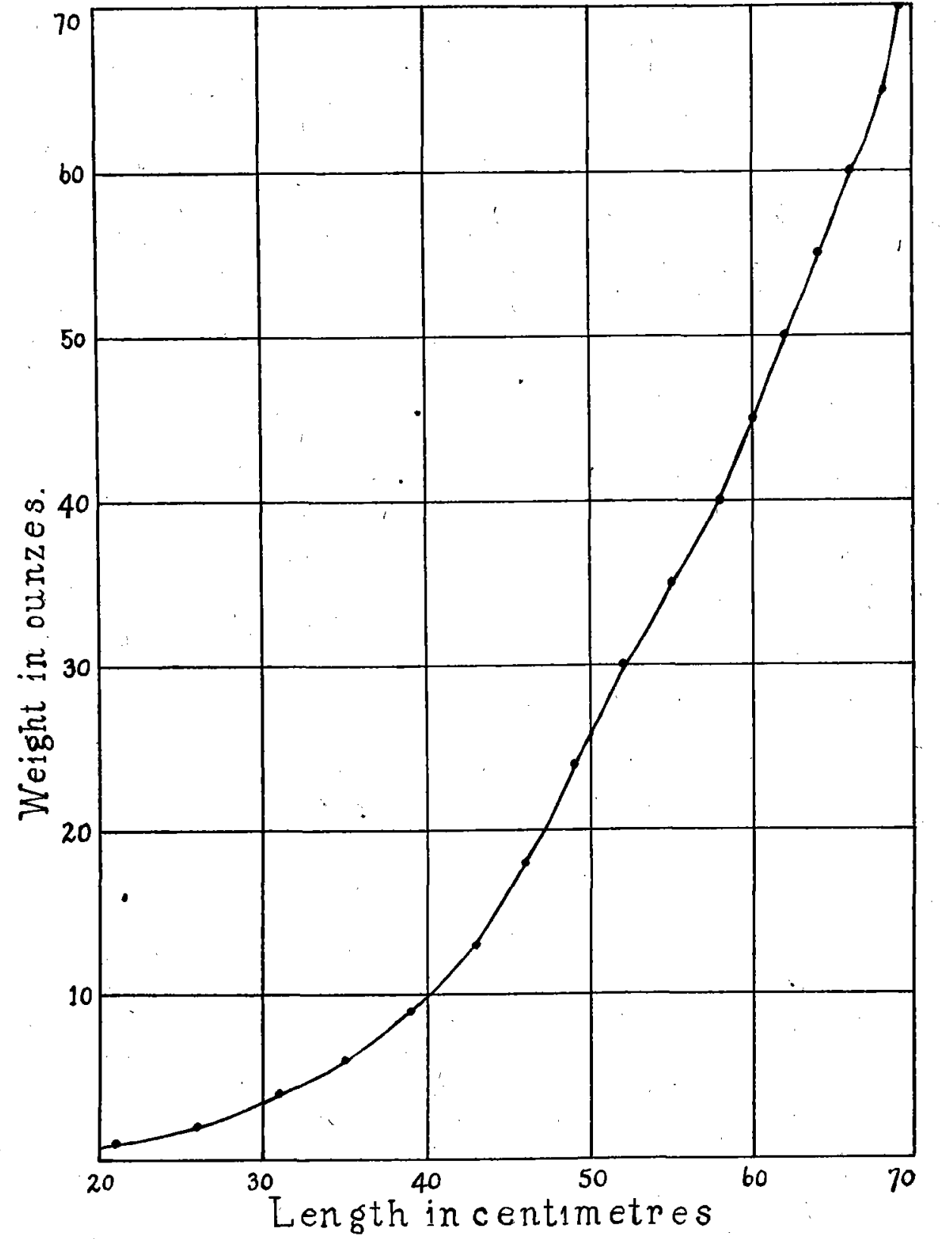

Fig. 5. Curve showing the relation of the length of the muttonfish to the welght.

These results indicate that the muttonfish is not a heavy fish in relation to its length and that the increase in weight in any year is not great.

There is no difference in weight between the sexes. The average weight of fourteen males in the tenth year of age, average length $49.4 \mathrm{~cm}$. was 1 pound, 9 ounces. The average weight of four females in the tenth year, average length $49.2 \mathrm{~cm}$., was 1 pound, 9 ounces. Similarly in the ninth year the average weights of the two sexes were almost identical. 


\section{FOOD.}

The contents of the alimentary tracts of seventy-five muttonfish were examined to obtain some data in regard to the food of the species. The records show that the muttonfish draws upon Molluses, Echinoderms and Crustaceans almost exclusively for its food. Of the 75 specimens examined, 59 had eaten Mollusca, 47 Echinodermata, and 40 Crustacea, percentages of 79,63 , and 53 , respectively.

- The relative abundance of the chief forms found in the digestive tracts of the 75 specimens is shown in the following table:-

\begin{tabular}{|c|c|c|c|}
\hline Name. & $\begin{array}{l}\text { No. of } \\
\text { Zoarces } \\
\text { in which } \\
\text { found. }\end{array}$ & Percentage. & $\begin{array}{l}\text { Greatest No. } \\
\text { found in a single } \\
\text { opecimen. }\end{array}$ \\
\hline 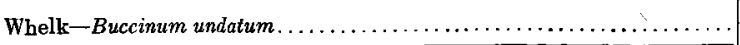 & 16 & 21 & 18 \\
\hline 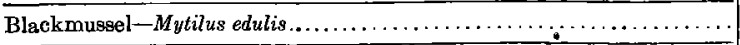 & 12 & 16 & 122 \\
\hline Modiolatia, various species........................... & 11 & 15 & 65 \\
\hline 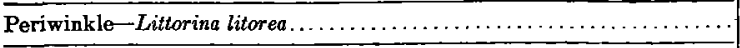 & 9 & 12 & 33 \\
\hline 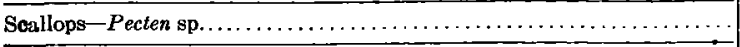 & 8 & 11 & 8 \\
\hline 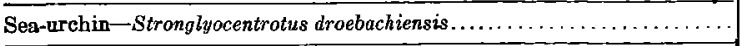 & $44^{\circ}$ & 59 . & 51 \\
\hline Brittle stars-Ophiopholis aculeata................................... & 9 & 12 & -7 \\
\hline Barnacle-Balanus balanoides...................................... & 14 & 19 & very numerous. \\
\hline 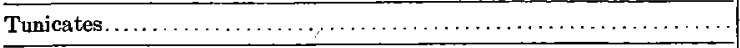 & 12 & 16 & 8 \\
\hline Polynoids.: & 10 & 13 & 4 \\
\hline
\end{tabular}

Two specimens had each eaten a small fish, one was a small smelt, (Osmerus $\operatorname{mordax}$; the other could not be identified. The following forms were kindly identified by Dr. A. G. Huntsman, Curator of the St. Andrews Biological Station.

\section{AnnUlata-}

Polynoids.

Phascolosoma sp?

Cistenides granulata (Malmgren).

Crustacea-

Pagurus kröyeri (Stimpson).

Pagurus acadianus (Benedict).

Erichthonius rubricornis (Stimpson).

Aeginella longicornis (Kröyer).

Nymphon grossipes (L).

Jaera marina (Fabr.).

Gammarus locusta (L).

Balanus balanoides (L).

Pycnogonum littorale (Ström).

Leptocheirus pinguis (Stimpson).

Unciola irrorata (Say).

Crago septemspinosus (Say).

Moluduša-

Modiolaria discors (L).

Modiola modiolus (L).

Buecinum undatum (L).

Margarita undulata (Sowerby).

Pecten magellanicus (Gmelin).

Aporrhais occidentalis (Beck).

Cardium pinnulatum (Conrad).

Velutina undata (Brown).
Moltusca-Continued.

Velutina laevigata (Gould).

Yoldia sapotilla (Gould).

Cyclocardia borealis (Conrad).

Polynices groenlandica (Müller).

Nucula tenuis (Montagu):

Crenella glandula (Totten).

Crenella decussata (Montagu).

Lyonsia hyalina (Conrad).

Littorina litorea (L).

Astarte undata (Gould).

Saxicava arctica (L).

Mya arenaria (L).

Acmaea testudinalis (L).

Solenomya velum (Say).

Corophium bonellii (M. E.).

Echinodermata-

Strongylocentrotus droebachiensis (Müller).

Ophiopholis aculeata (L).

Echinarachnius parma (Lamarck).

\section{Chordata-}

Ascidiopsis prunum (Müller).

Caesira retortiformis (Verrill).

Tetradidemnum albidum (Verrill). 
Storer (1839) lists the following as stomach contents:-

Buccinum undatum.

Fusus corneus.

Fusus pleurotomarius.

Turbo inflatus.

Natica triserata.

Natica consolidata.

Bulla tritacea.

Tellina sordida.

Storer (1867) lists these additional forms-

Turbo obscurus.

Fusus turricula.

Trichotropis borealis.

Nucula minuta.

Turritella erosa.

Venus gemma.

Pecten islandicus.

Pectinaria sp.

The results of the food study show that the muttonfish is a bottom feeder but is not a scavenger.

\section{IIST OF ASSOCIATES FROM SET LINE RECORDS.}

Considerable information regarding the common associates of the muttonfish in the St. Croix river is obtained from the set line records as shown in the following table, in addition to that afforded by the study of the food. The records were obtained between May 31 and August 19, 1918. The area covered was from the mouth of the river to about 10 miles upstream at depths from 10 to 30 metres. An average of 250 hooks was used at a set and the line usually, set for an hour either at high or low water slack. Clams (Mya arenaria) and herring (Clupea harengus) were used for bait as shown in the table:-

\begin{tabular}{|c|c|c|c|}
\hline & $\longrightarrow$ & $\begin{array}{c}\text { Clam } \\
\text { bait, } \\
19 \text { sets. }\end{array}$ & $\begin{array}{l}\text { Herring } \\
\text { bait, } \\
\text { to sets. }\end{array}$ \\
\hline $\begin{array}{l}\text { Anemones........... } \\
\text { Crabs } \\
\text { Horse mussel, } \\
\text { Whelk, } \\
\text { Round whelk, } \\
\text { Common starfish, } \\
\text { Sea urohins, } \\
\text { Basket stars, } \\
\text { Crossaster, } \\
\text { Blood star, } \\
\text { Brittle stars, } \\
\text { Sea-cucumber, } \\
\text { Sea pear, } \\
\text { Sea peach, } \\
\text { Sea potato, } \\
\text { Tobacco box, } \\
\text { Spiny skate, } \\
\text { Barn door skate, } \\
\text { Dogfish, } \\
\text { Haddock, } \\
\text { Hake, } \\
\text { Cod, } \\
\text { Tomcod, } \\
\text { Rosefish, } \\
\text { Sculpin, } \\
\text { Sea raven, } \\
\text { Flounder, } \\
\text { Halibut, } \\
\text { Eelpout or Muttonfisb, }\end{array}$ & 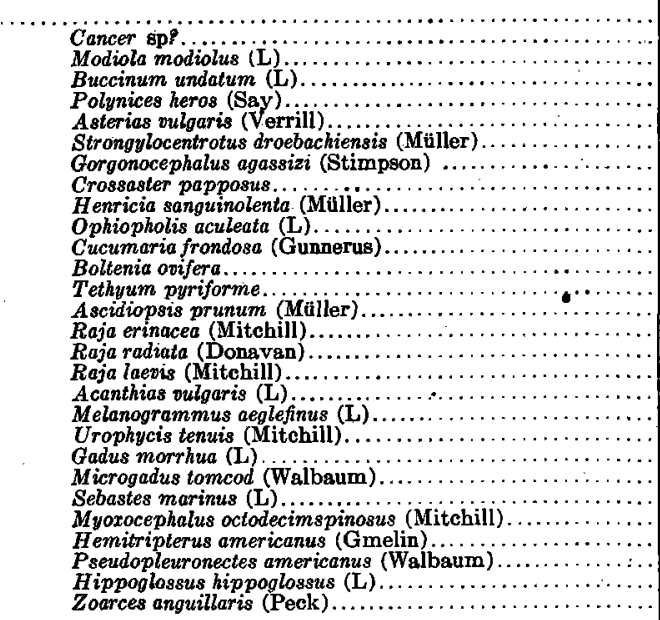 & 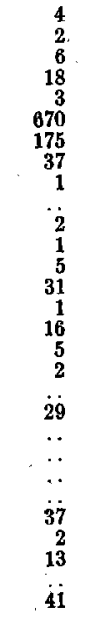 & $\begin{array}{r}6 \\
\mathbf{1} \\
\mathbf{5} \\
\mathbf{1} \\
\mathbf{3} \\
\mathbf{9 2} \\
\mathbf{4 2} \\
\mathbf{4 4} \\
\mathbf{2} \\
\mathbf{1} \\
10 \\
\mathbf{1} \\
18 \\
\mathbf{9} \\
\mathbf{1} \\
\mathbf{1 1 3} \\
\mathbf{9} \\
\mathbf{7} \\
\mathbf{1} \\
\mathbf{2} \\
\mathbf{2} \\
\mathbf{2} \\
\mathbf{5} \\
\mathbf{4} \\
\mathbf{4 8} \\
\mathbf{1} \\
\mathbf{2} \\
\mathbf{1} \\
\mathbf{9}\end{array}$ \\
\hline
\end{tabular}

$79550-6$ 


\section{ENEMIES.}

Only three fish have been found to have eaten the muttonfish, a sculpin (Myoxocephalus octodecimspinosus), a sea raven (Hemitripterus americanus), and a skate (Raja laevis). The first had eaten a small specimen, $3.7 \mathrm{~cm}$. in length. The other two had eaten the muttonfish after the latter had taken the hook of the set line.

\section{PARASITES.}

Considerable parasitism by nematode and platyhelminth worms occurs in the alimentary tract, and by nematodes in the body muscles. Of 44 specimens examined for intestinal parasites, 45 per cent contained nematodes and 35 per cent tapeworms. The nematodes were kindly identified by Mr. Maurice C. Hall, of the Bureau of Animal Industry, Washington, D.C., as Kathleena sp. and Echinorhynchus sp., both probably undescribed species. The tapeworms have been kindly identified by Dr. A. R. Cooper, University of Illinois Medical School, Chicago, Ill., as Bothrimonus intermedius Cooper.

Of 41 specimens examined for body-muscle parasites from July 26 to October 15 , 1918, 60 per cent were parasited. These were also identified by Mr. Hall as Kathleena sp. ?, probably undescribed species. Similar nematode worms have been found in the body muscles of flounders (Pseudopleuronectes americanus) and cod (Gadus morrhua) taken in the same region. Possibly this parasitism may be only local or only occur to any extent in certain years.

\section{SUMMARY.}

The important points brought out in this study of the muttonfish (Zoarces) in the Passamaquoddy bay region are:-

1. That it leaves the rivers and bays in the fall of the year for the outer deeper waters of the Atlantic, and returns about the end of April of the following year.

2. That the reproductive period occurs in the autumn.

3. That the fish is comparatively slow of growth, reaching a length of about $70 \mathrm{~cm}$. and a weight of 69 . ounces at 20 years of age.

4. That it is a bottom feeder, feeding almost entirely upon Mollusca, Echinodermata and Crustacea.

BriDge, T. W.

\section{LITERATURE CITED.}

1904. Fishes.

Cambridge Natural History, London. (419.)

Clemens, Wilbert A.

1920. The Muttonfish.

Bull. 4, Biol. Board Can., Ottawa.

Fryd, Carlos.

1901. Die Otolithen der Fische.

Inaugural Dissertion.

Goode, George Brown.

1884. The Fisheries and Fishing Industries in the United States.

Washington. 
Lea, Einar.

1919. Age and Growth of Herring in Canadian Waters.

Canad. Fisheries Expedition 1914-15. Dept. Naval Service, Ottawa.

- McIntosh, W. C.

1885. Reproduction and Development of Fishes.

3rd Ann. Rept. Fish. Board Scotland, App. F. No. III (57).

NichoLs, J. T.

1916. Seasonal Annotations on two Long Island Fishes.

Copeia, No. 27 (10).

Peск, Wm. D.

1804. Descriptions of Four Remarkable Fishes.

Mem. Amer. Acad. Arts \& Sci. 2 (46).

STORER, DAVID Humphreys.

1839. A Report on the Fishes of Massachusetts.

Boston Journ. Nat. Hist. 2 (289).

1867. A History of the Fishes of Massachusetts.

Mem. Amer. Acad. Arts \& Sci. (N.S.), 5 (263).

Van Bambeke, Ch.

1888. Remarques sur la reproduction de la Blenne vivipare (Zoarces viviparus Cuv.).

Bull. de l'Academie Royale des Sciences Belgique No. 1, 3rd serie, 15 (92-117). 